\title{
Eight challenges of servitisation for the configuration, measurement and management of organisations
}

\begin{abstract}
There is an extensive research literature on servitisation and the related field of product service systems that has emerged independently from different fields including engineering, management, design and environmental studies. The purpose of this paper is to conduct a structured literature review to explore, identify and synthesise the multidisciplinary research challenges in the journey towards servitisation. The research approach is a systematic literature review using key word searches and citation tracking for research reported between 1990 and 2013 in research databases that cover the fields which have generated the body of knowledge. One of the key findings from the extant literature on servitisation is that it suffers from three fundamental weaknesses. First, numerous studies are conceptual in nature with limited practicality. Second, there are relatively few empirical studies, and often the findings relate to a single case study based on the insights of a limited number of senior managers. Third, often the dynamics are insufficiently studied in these organisations because data for most cases are collected post-event. Based on the literature review and its shortfalls, this paper proposes a holistic framework of eight themes that require further attention from academic researchers in order that a more complete conceptual understanding of servitisation is developed to support practice.
\end{abstract}

Keywords: Servitisation, Product Service System, Competitive Advantage, Holistic Framework

\subsection{Introduction}

In the quest for differentiation and competitiveness, service has become ubiquitous (Baines and Lightfoot, 2014). With an increasingly pivotal role in today's knowledge-based economies, services are receiving considerable attention from academics and practitioners (Gronroos, 2000; Prahalad and Ramaswamy, 2004; Spohrer and Maglio, 2008). The trajectory of growth of the service economy underpins the notion of servitisation, which increasingly requires a shift in perspective, from value-in-exchange towards value-in-use (Vargo and Lusch, 2008; $\mathrm{Ng}$ and Nudurupati, 2010; Neely, 2012). This new emphasis is further echoed in Product Service System (PSS) studies (Meier et al. 2010; Lamvik, 2001; Morelli, 2002). Despite an established definition of PSS as offering "goods and services that are consumed over time in multiple consumption episodes" (Mittal et al., .1999), there remains a lack of clarity concerning the concept: some researchers refer to PSS as a "value proposition" (Tucker and Tischer, 2006), others refer to it as an "innovation strategy" to remain commercially competitive (Manzini and Vezzoli 2003). Additionally, other researchers refer to PSS as a "concept", "form", "structure" or "platform" from which to innovate efficient "systems" and "models" for the benefit of the consumer (Bullinger et al., 2003; Mont 2002). Regardless, this suggests that, whether the value to the customer is delivered through products or services, the value chain should be viewed from a customer perspective (Wise and Baumgartner, 1999) and how the customer uses the product/service throughout its life cycle (Vargo and Lusch, 2004), including its impact on the environment (Manzini and Vezzoli, 2003; Mont, 2002). It is further argued that the purpose of 
integrating service with existing products improves competitiveness as well as identifying balance between social, economic and environmental factors (Yang et al, 2009).

The transition from product-dominant to service-dominant thinking is challenging for both researchers and practitioners, requiring fresh and innovative thinking as to how organisations need to be configured, measured and managed ( $\mathrm{Ng}$ and Nudurupati, 2010). The combined product/service offering creates pressure on organisations to fulfil contractual obligations to customers who have extremely diverse and unpredictable requirements, coupled with an internal pressure to deliver the offering as economically as possible (Baines et al., 2011). Moreover, servitisation requires organisations to build new people skills, technologies and capabilities (Reinartz and Ulaga, 2008). However, despite the growing volume of academic papers on the subject, our knowledge of the practicalities of implementing product-service systems is still fairly meagre. There is a theoretical and practical need to understand the drivers of success and failure of the transition from product-dominant to service-dominant logic within business organisations ( $\mathrm{Neu}$ and Brown, 2008). It has been argued that a paradigm shift is necessary in the way organisations work, to create a strong focus on outcome driven culture and risk sharing agreements, in their journey towards servitisation (Barnett et al., 2013). Much previous research has been theoretical, prescriptive or based on single organisation case studies, thus limiting the generalisation of findings and potential application of lessons to other organisations, industries or sectors (Johnstone et al., 2009). The aim of this paper is to review the literature, identify the core issues and classify the research and organisational challenges into a framework of fundamental themes that forms the basis for a research agenda.

\subsection{Research Design}

The overall approach comprises a thematic analysis of the content of key contributions to the body of work concerning servitisation. A systematic literature review (Denyer and Tranfield, 2008; Rousseau et al., 2008) was performed on servitisation and product service system subjects (Figure 1). Predefined search strings employed in the keyword searches included "servitisation", "product service systems", "service design" and "service innovation". These searches were used to identify articles published between 1990 and 2014 in specific databases: Business Source Premier, Emerald Insight and Science Direct. Furthermore, a number of specific journals were chosen for particular scrutiny because they attract a large number of papers in the field of service research. Similarly, papers were also identified through citation tracking from the initial selection of papers. This approach thus facilitated the exploration of a broad range of servitisation challenges from a product based organisation perspective (as advocated by Bititci et al., 2012).

The initial key word and journal database searches yielded around 300 articles. On the basis of titles and abstracts, these articles were further filtered to obtain 40 papers. The criteria used for filtering the papers the assessment of whether a paper was focussed on servitisation and/or product service systems. These 40 papers were further supplemented by an additional 20 papers obtained through citation tracking. These 60 papers are the basis of the analysis from which the themed challenges were derived. Whilst all of these papers were appraised fully in order to conceptualise the current servitisation research in product-based organisations, twelve were selected for thorough investigation. The choice of these papers was to triangulate the clusters 
and validate the framework. These papers were judged empirically validated and rigorous and are central in the field in developing the challenges of servitisation. So, our approach was to use the most credible papers that we identified as the core of our consideration of the validity of our framework of challenges. It was part of our undertaking to carry out a thorough critical review of the available research papers. From this, we identified the most robust contributions from which to derive our overview and summary of the implications of the extant literature on servitisation.

A grounded theory approach to coding the content of this body of literature was used to reveal the themes without imposing preconceived mindsets and ideas (Glaser and Strauss, 1967). We chose not to use software in the coding process, and believe it important to explain this here. In our view, the integrity of coding is entirely dependent on the skills and rigor of researcher(s). Certainly, for a literature application such as ours, we reject the facility in NVivo that allows for automatic coding. The papers we used as our source documents we formatted in different ways and used different spelling and grammar conventions. They also used different terms to convey the same meaning. This meant that interpretation at a micro-level was important in evaluating our materials. We were looking further than to understand themes in the documents as would be the objective of using NVivo for the analysis of empirical qualitative data. Instead, we sought to make a judgement on the veracity of the research presented in the papers. In other words, it was not only the content of the work that we assessed, but also the quality. This was especially important in our first stages of filtering the material in our core articles. In this sense, we felt that the use of NVivo could potentially undermine the quality of our analysis rather than enhance it. We considered the purpose, theoretical base, methods, investigations, findings and conclusions for each paper.

Moreover, we felt that the use of NVivo could prejudice and limit us as investigators, we did not want to fall into the trap of relying on the software instead of understanding the material and identifying the hidden and subtle trends and codes. In practice, the investigators worked independently and then together in order to arrive at the codes and created the clusters that are documented in Table 1. These were triangulated against the twelve papers selected for thorough investigation. In this analysis, key point coding was utilised in preference to microanalysis coding (Allan, 2003; Cranfield and Taylor, 2008). Pragmatically, we also drew on our experiences of reviewing and examining research that has used NVivo in the analysis of a literature review and we are of the view that although it has potential, it potentially fails to add value and insight. Indeed, we have experienced instances when using NVivo has appeared to be a substitute for critical analysis and masked some important points that could only be revealed through reader interpretation. The differences and quality of contributions of the papers we scrutinised were often subtle, and we deemed that identification of such would not be aided through the use of NVivo. 


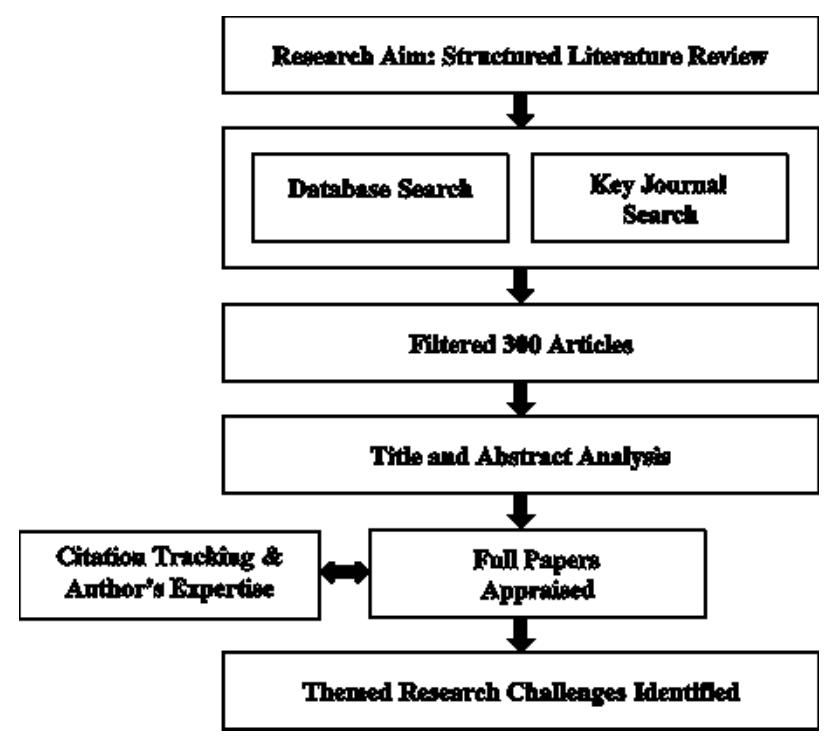

Figure 1: The methodological basis for the literature review

\subsection{Integrating Products and Services: an analysis of the extant literature}

The innovative integration of services with products to deliver value-adding customer benefits to enhance competitive advantage has been a developing stream of literature over the last 25 years (Wise and Baumgarter, 1999; Oliva and Kallenberg, 2003; Neely, 2007; Spring and Araujo, 2009; Baines et al., 2009; Baines and Lightfoot, 2014). The principle of a firm offering bundles of customer-focussed combinations of products with services such as support services, self-services and knowledge services has become termed servitisation (Vandermerwe and Rada, 1988). The general management literature refers to this impact of services as the "servitisation of products" or "servicising" (White et al., 1999), suggesting that the old dichotomy between product and service is being replaced by a service-product continuum (Lovelock and Gummesson, 2004; Zeithmal et al., 2006). Consequently, in the services marketing literature, Vargo and Lusch proposed the term "service dominant logic" to theorise two premises. First that "goods are a distribution mechanism for service provision" and second, "all economies are service economies" (Vargo and Lusch, 2004).

The integration of manufacturing and services is seen as an effective means for growing and/or maintaining profits, plus potentially significantly increasing control over the downstream elements of the supply chain by erecting barriers to rivals or new entrants (Mathe and Shapiro, 1993; Schmenner, 2009). Neely, (2012) summarises the purpose of servitisation into three categories of benefits: economic, strategic and environmental. However, according to Fang et $a l .$, (2008), the benefits of servitisation strategies to the organisation only become obvious when the level of associated service sales reach approximately $20-30 \%$ of total earnings. Furthermore, these benefits are dependent on how well the organisation leverages its unique resources to build distinctive capabilities (Ulaga and Reinartz, 2011).

\section{Servitisation and PSS}

The servitisation movement is also reflected in the "Product Service System (PSS)" research, largely derived from the engineering and environmental disciplines (Mont, 2003; Manzini and Verzolli, 2003). PSS refers to "a marketable set of products and services jointly capable of 
fulfilling client's needs" (Goedkoop et al., 1999). PSS is also understood as a "functionoriented business model" where "tangible products and intangible services are combined so that they are capable of fulfilling specific customer needs" (Tukker, 2004). PSS signifies a competitive opportunity for many organisations by reducing consumption through modification of their products by integrating services (Beuren et al., 2013). In general, the classification of PSS falls into three categories: product-oriented, use-oriented and resultoriented services (Brezet et al., 2001; Cook et al., 2006; Zaring, 2001). In product-oriented services PSS, the ownership of the "material product" is considered as transferred to the customer and a service arrangement is provided to 'ensure the utility' of the artefact over a given period of time. This is different to use-oriented PSS which refers to a configuration in which the ownership of the "material product" is retained by the service provider who sells the "function" of the product to the customer. A typical example of this is leasing products such as photocopiers, DVDs and cars. In the result-oriented PSS, the service provider sells "results" rather than "functions". In other words, the customer purchases "utility" as an outcome instead of the "function" of the product and typically, under the result-oriented PSS, there is nopredetermined product involved (Cook et al., 2006). Similarly, Neely (2012) discusses five different options ranging from integration oriented PSS to results oriented PSS on a servitisation continuum: integrated, product, service, use and results oriented PSS Neely articulates that each of these options provide different opportunities for organisation to servitise.

PSS and servitisation have essentially the same aim: to provide competitively a solution that meets the needs of the customer throughout the lifecycle of the offering and increase an organisation's competitiveness and profitability (Geng et al., 2010). The competitiveness of the value proposition is derived not only from how innovatively an organisation develops the combination of products with services, but depends also on how the value proposition can be delivered with minimum disruption to the customer's business processes (Johnstone et al., 2009). Whilst there are numerous ways of configuring the resources of an organisation to create competitive advantage, few organisations have tended not to invest in developing an understanding of the complementary services needed to leverage the competitiveness of their products (Anderson and Narus, 1995). Typically, management teams neglect to understand customer service needs fully and provide the services required including standard and optional offerings and the best ways of delivering them. Hence, Baines et al (2013, p638) identified three categories of services and categorised them as basic, intermediate and advanced. The emphasis of a basic service is to focus on providing products to the customer, whereas the emphasis for an intermediate service is to focus on providing condition maintenance, advanced service focuses on providing assurance of outcomes. It could be argued that providing advanced service is an important element of servitisation and it involves organisational transformation.

\section{Manufacturing innovation}

Neely (2012) argues that servitisation is a journey in which a manufacturing firm innovates its capabilities and processes to shift its focus to delivering integrated product-service systems that deliver value-in-use. Furthermore, there are various forms of product-service combinations, which often involve a shift from selling a product to customers towards other transactional forms such as leasing, hiring, pooling and pay for use, availability or performance (Spring and 
Araujo, 2009). An additional challenge for the organisation is to understand the changing nature of its collaboration with customers. The distinctive feature of this transition is in the retention of ownership of the product by the organisation, which results in changes to cost structures as well as a re-distribution of risks and incentives between the parties involved. This challenge is amplified and becomes even more complex when the organisation shares its resources across multiple contracts, each with different degrees of involvement with customers. This situation is prevalent in complex engineering service systems such as those with the defence industry (Ng and Nudurupati, 2010). Benedettini and Neely (2012) argue that the importance of the complexity of manufacturing companies stems from the complexity of the product supplied and the context in which the associated services are offered rather than the service itself.

In the servitised environment, management teams within business organisations need to move away from a mind-set that delineates manufacturing as a separate entity from service activities, because both offer service-based value to enable customers to perform their own processes effectively (Quinn et al., 1990). Hence, it is important to consider both aspects when designing the combined offering. However, most research concerning PSS design limits its focus to methodologies for attaining environmental benefits (Sakao et al., 2009; McAloone and Andreasen, 2004; Morelli, 2009). There is an established argument for organisations to re-think the way in which they produce (White el al., 1999) and that a functional economy will be one in which the focus of consumption is not goods per se but on the services that those goods deliver and is also closely associated with the concept of eco-efficiency. The central issue addressed in the design of PSS is the belief that both the analysis of technological potential and the investigation of users' behaviour and attitudes are essential to the success of the PSS (Morelli, 2002) . Successful PSS design depends on a thorough understanding of the interactions, or touch-points, occurring over the life cycle of the offering (Sakao et al., 2009). These interactions encapsulate different human, behavioural, cultural, mechanical and institutional factors (Morelli, 2009).

Organisations engaging in the transition to these "combined offers" must look beyond the immediate transactions with their customers in order to provide the appropriate offering (Johnstone et al., 2009). Hence they need intimate knowledge of the customer's operations when designing their own value proposition (Gummesson and Polese, 2009; Redatts and Easingwood, 2010). Smith et al., (2014) offered four value propositions for delivering valuein-use within the context of servitisation: asset, recovery, availability and outcome based value propositions. They argue that the role and importance of contextual variety increases going through these value propositions from asset to outcome based propositions. Integrating diverse knowledge areas throughout the lifecycle of the offering requires integrated teams encompassing several areas of skills and expertise (Edvardsson et al., 2000). Therefore, knowledge area linkage in a service system becomes a networked activity across company boundaries.

A major problem in PSS development is the lack of shared understanding with respect to the many disciplines and functions involved in the development process (Johansson et al., 2011). A suggested methodology for gathering knowledge to support the design of a PSS, involves network mapping, network actor profiling, multi-media data capture and process blueprinting 
(Morelli, 2009). The aim is to develop enriched and explicit knowledge to enable the design of a more compelling value proposition. A process of modularisation to enable organisations to create a portfolio of elementary building blocks for the product and service design process has been proposed, so that the network partners could make use of equivalent building blocks individual configuration of supporting elements for specific customer requirements (Aurich et al., 2006). Building on this, a modified Quality Function Deployment (QFD) tool demonstrates how the products and services should be jointly developed during the design phase to satisfy customer needs (An et al., 2008).

\section{Servitisation capability for competitive advantage}

Five distinctive capabilities have emerged (Figure 2) that organisations must develop by deploying four unique resources for a competitive advantage (Ulaga and Reinartz, 2011). Organisations in their journey towards servtisation could use these unique resources to create distinctive capabilities thus generating competitive advantage. Although logical and coherent, these are derived only from the organisational perspective of the dyad and so need further validation from the suppliers/customers perspectives for general applicability. It should be noted that the capabilities, competences and resources of the organisation have to match the combined offer provided for the contextual needs of the customer (Windahl et al., 2004). The associated people skills required to develop these resources and capabilities are scarce and one limiting factor is that many research agenda-setters and policy-makers still treat manufacturing and services as distinct disciplines (Spring and Araujo, 2009). There is a need to develop graduates with multidisciplinary skills rather than specialist knowledge in just one field. Contemporary management textbooks tend to place insufficient attention on the detailed integration of manufacturing and services at the level of configuration of internal resources to deliver the combined offering (Heineke and Davis, 2007). A similar issue has been identified in marketing science, with advocates emphasising the need to shift its focus towards a world in which service and relationships dominate (Anderson, 2006).

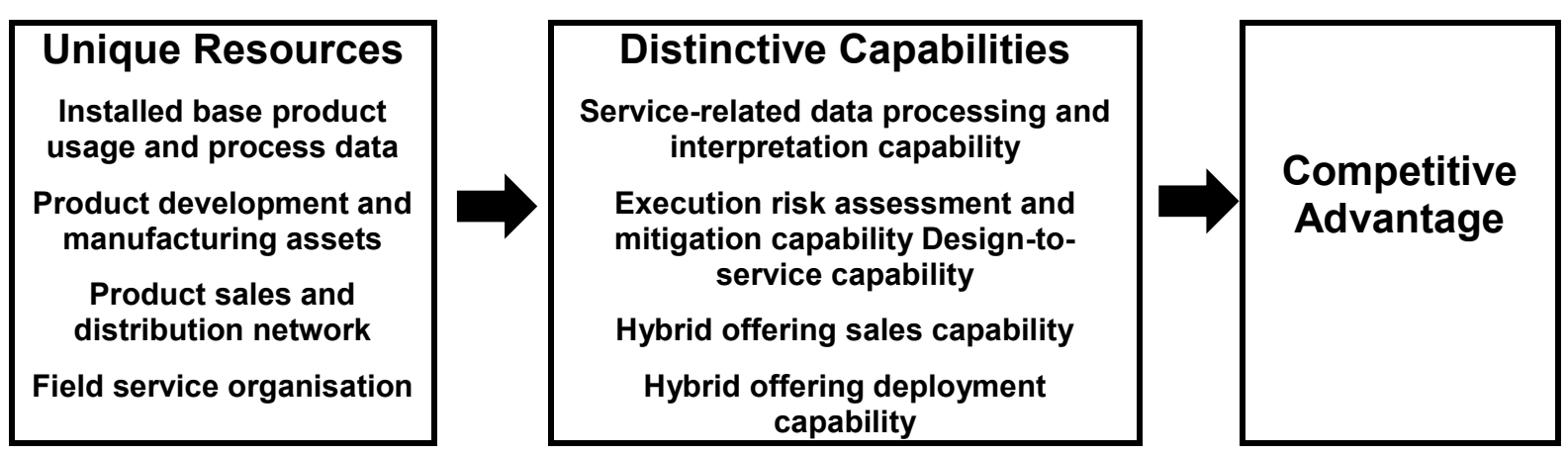

Figure 2: Organisation specific resources and capabilities for competitive advantage (source: Ulaga and Reinartz 2011, p10)

It has been argued that the goal of an organisation is to develop on-going relationships with customers, suppliers and complementors to jointly develop and deliver the offering (Spring and Araujo, 2009). In this context, the key challenge for the organisation is to design an appropriate combination of risk-pooling capacity and contracts with customers: there is a need to develop methods and models for distributing the risks across the various actors in the organisation's network. The contextual needs of individual customers evolve constantly over time and it is crucial for the organisation to track their perceptions of new offerings via marketing research in order to detect risks. Major organisational changes are needed to create flexible modes of 
delivery to enable the customer to realise the maximum value from the offering (Brady et al., 2005). Overall, the key issue for the organisation is to deploy the necessary capabilities to enable the customer to co-create value with them to deliver value-in-use (Vargo and Lusch, 2008). This focus on organisations and customers co-creating value by integrating their resources (Barrutia and Gilsanz, 2012) has become an enduring notion in the servitisation paradigm. Since the customer plays an active part in delivering value-in-use, it is necessary to understand and capture knowledge on their individual behaviour (Aurich et al., 2010).

$\mathrm{Ng}$ et al. (2009) identified seven co-creation attributes that are useful in delivering value-inuse outcomes (advanced services as articulated above): behavioural alignment, process alignment; congruence in customer expectations; congruence in firm expectations; empowerment and perceived control; behavioural transformation, and complementary competencies. These seven attributes enable value co-creation with customers and their impact on organisational capability to deliver complex combined offerings. It is argued that an organisation's capability should be configured to enable effective co-creation through a valueweb (capability integration perspective), rather than delivering its value proposition through a value chain (vertical integration perspective) (Ng et al., 2011). Similarly Martinez et al., (2010) explored five challenges that organisations should address in their journey towards servitisation: embedded product-service culture, delivery of integrated offering, internal processes and capabilities, strategic alignment and as supplier relationships (all in the servitised context). Both these studies emphasise the importance of transforming an organisation's service culture and aligning it to customer's values and perceptions to maximise value-in-use, a notion echoed generally in the body of service research (Sakao et al., 2009; Johnstone et al., 2009; Edvardsson et al., 2000). The operations strategy for developing a servitsed offering should be a subtle blend of the two extremes of pure product and pure service associated operation strategies (Baines et al., 2009). Based on this belief they identified how an organisation should develop and build their structural (process and technology, capacity, facilities, supply chain positioning, planning and control) as well as infrastructural (human resources, quality control, product/service range, new product/service introduction, performance measurement, supplier relations and customer relations) characteristics. Similarly, Baines et al. (2013) identified six behaviours and their associate skills-sets that are crucial in the successful delivery of advanced services that emphasise the delivery of outcomes.).

Organisations that are "vertically integrated" (through actions such as locating their facilities closer to the customer operations and understanding, monitoring, conditioning and servicing of sophisticated technology systems and their use) would ensure speed and effectiveness of their response to customer needs while minimising their costs (Baines et al., 2011). Additionally, several areas are affected within the organisation in this transition journey, these include facilities, information and communication technologies, performance measurement systems, organisational processes and human resources. In the servitised context, five relationship behaviours have been identified (information exchange, operational linkages, legal bonds, co-operative norms as well as buyer and supplier adaptation) (Bastl et al., 2012). However, most studies are derived either from single case studies or the views of a few selected senior managers, limiting their generalisation. Hence, more empirical research is needed to 
identify models, methods, tools, techniques and procedures to support organisations in the development of offerings that are economically viable.

\subsection{Discussion - Research Agenda and Management Implications}

Our review of servitisation research shows that a considerable body of literature has developed over the past twenty-five years. This research has emerged independently, from different fields including engineering, marketing, management, environmental and design studies. As a consequence, the extant literature pertaining to servitisation does at times appear fragmented and suffers from three fundamental weaknesses. First, numerous studies are theoretically conceptual in nature with limited practicality (Barrutia and Gilsanz, 2012; Beuren et al., 2013). Second, there are relatively few empirical studies, and often the findings relate to a single case study based on the insights of a limited number of senior managers. This again limits the applicability of the findings across organisations. Third, often the dynamics are insufficiently studied in these organisations as data for most cases are collected post-event. A pragmatic approach might be to develop a multi-disciplinary research framework based on the challenges that product-based organisations must overcome in order to implement effective strategies. With these limitations in mind, though research challenges are discussed in the context of our evaluation of all 60 papers, twelve contributions were chosen for thorough investigation. These papers report research from which the findings are strongly supported by robust empirical studies, and these are the basis of our development of a multi-disciplinary research framework, represented in Table 1.

\begin{tabular}{|c|c|c|c|c|c|c|c|c|c|}
\hline Research Challenge/Theme & 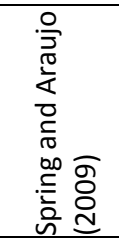 & 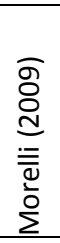 & 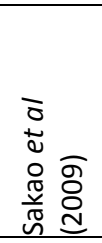 & 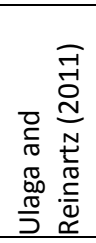 & 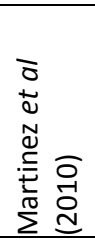 & 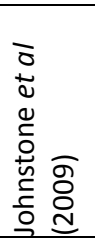 & 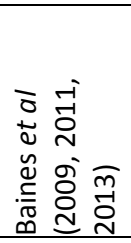 & 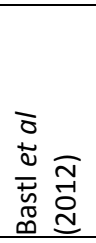 & 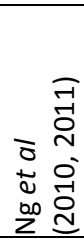 \\
\hline Theme 1: Customer Perspective & & $\checkmark$ & & $\checkmark$ & & $\checkmark$ & $\checkmark$ & & $\checkmark$ \\
\hline Theme 2: Redefining the Interface & $\checkmark$ & & & $\checkmark$ & & & & & $\checkmark$ \\
\hline Theme 3: Revenue, Pricing \& Selling & & & & $\checkmark *$ & & & & & $\checkmark * *$ \\
\hline Theme 4: Product/Service System Design & & $\checkmark$ & $\checkmark$ & $\checkmark$ & $\checkmark$ & $\checkmark$ & $\checkmark$ & & $\checkmark$ \\
\hline Theme 5: Supply Network & $\checkmark$ & $\checkmark$ & & & $\checkmark$ & & $\checkmark$ & $\checkmark$ & \\
\hline Theme 6: Organisational Architecture & & & $\checkmark$ & & & $\checkmark$ & $\checkmark$ & & $\checkmark$ \\
\hline Theme 7: Performance Measurement & & & & & & & $\checkmark$ & & \\
\hline Theme 8: Cultural Transition & & & & & $\checkmark$ & $\checkmark$ & $\checkmark$ & & \\
\hline$\checkmark^{*} \quad$ Addresses sales/selling & Iddress & rev & /pric & & & & & & \\
\hline
\end{tabular}

Table 1: Research Challenges/Themes Matrix with Supported Literature

The outcome of the multi-disciplinary thematic analysis of the literature concerned with the various challenges of product-based organisations in their journey towards servitisation was the synthesis of eight themes, presented in Figure 3.

The first theme is to explore the customer perspective, where understanding value-in-use plays a significant role in contrast to product requirements. Although few authors have conducted research and attempted to develop tools and techniques (Ulaga and Reinartz, 2011; Morelli, 2009) for understanding value-in-use, it is not yet completely clear how to develop such a 
capability and its associated resources to explore the contextual variety of customer needs. Based on an understanding of these contextual needs, an organisation has to explore different ways of addressing them, which leads to the second theme of redesigning the interface with the customer. In other words, an organisation has to decide whether to aim for gaining competitive advantage through transferring or retaining the ownership of product to/from the customer and perform the associated services. This leads to an exploration of different contracting approaches, such as leasing, renting, availability or performance based contracts. However, the challenge here is to find which contracting mechanism is optimally economical and beneficial to both parties. Despite the identification of various risks involved in outcome based contracts for complex engineering services, the findings are limited to a specific industry $(\mathrm{Ng}$ and Nudurupati, 2009). Hence, there is a need for more research to explore the different risks and incentives involved in these approaches and how to re-distribute them.

\begin{tabular}{|c|c|c|}
\hline $\begin{array}{l}\text { Customer Perspective } \\
\text { - How to develop capability to } \\
\text { understand the contextual } \\
\text { variety of customer needs } \\
\text { - What are the resources needed } \\
\text { to build this capability } \\
\text { - What are the tools and } \\
\text { techniques? }\end{array}$ & $\begin{array}{l}\text { Redefining the Interface } \\
\text { - How to identify economically } \\
\text { sustainable approach to liaise } \\
\text { with customer } \\
\text { - What are the risks and } \\
\text { incentives in the approach } \\
\text { - How to re-distribute them }\end{array}$ & $\begin{array}{l}\text { Revenue, Pricing \& Selling } \\
\text { - How to price the offerings? } \\
\text { - Are the offerings economically } \\
\text { viable } \\
\text { - Do we need new sales } \\
\text { capability? Why? } \\
\text { - What are these capabilities and } \\
\text { associated resources }\end{array}$ \\
\hline $\begin{array}{l}\quad \text { Cultural Transition } \\
\text { - What skills are required and how } \\
\text { to source or develop them? } \\
\text { - What behaviours are developed } \\
\text { and transformed? } \\
\text { - Is there an appropriate } \\
\text { management style to lead this } \\
\text { journey? }\end{array}$ & ( & $\begin{array}{l}\text { Product/Service System Design } \\
\text { - Do we need a new approach for } \\
\text { this design? } \\
\text { - What methods, tools and } \\
\text { techniques are available? } \\
\text { - What organisation capabilities and } \\
\text { their associated resources } \\
\text { required? }\end{array}$ \\
\hline $\begin{array}{l}\text { Performance Measurement } \\
\text { - How to measure value-in-use } \\
\text { through life? } \\
\text { - What are the metrics? } \\
\text { Is it necessary to involve } \\
\text { customer in evaluating the } \\
\text { offering through life? If so how? }\end{array}$ & $\begin{array}{l}\text { Organisational Architecture } \\
\text { - What structural changes are } \\
\text { required in the organisation? } \\
\text { - What changes are required to } \\
\text { the infrastructure \& resources? } \\
\text { - How to capture and manage } \\
\text { knowledge on all aspects of this } \\
\text { journey? }\end{array}$ & $\begin{array}{l}\text { Supply Network } \\
\text { - Are the current suppliers } \\
\text { affected in this journey? } \\
\text { - Do they need to redefine their } \\
\text { relationships? If so how? } \\
\text { - Do they need to vertically } \\
\text { integrate? To what extent? }\end{array}$ \\
\hline
\end{tabular}

Figure 3: A holistic framework for research challenges of product-based organisations

Further challenges in this theme are concerned with defining the use, availability and performance of the product, how to measure them, and how to allocate necessary resources. Due to the uncertainty in the nature of services consumed, which are often state-dependent and contextual in nature, it is difficult to establish the necessary resources required to provide that service, making the pricing of the service complex (Bakos and Brynjolfsson, 1999).

If services are overpriced, the organisation will be less competitive and lose revenue, and if the services are under-priced, the organisation will suffer a loss of income. This leads us to the third theme of revenue, pricing and selling. Organisations need to know how to price their 
offerings and assess whether the additional services result in expected revenue generation. Organisations need to explore whether they need additional capabilities in selling the servitised offering. Future research needs to focus on identifying additional selling capability and associated resources.

Much literature has already reported issues concerning the design of product/service systems, predominantly from a sustainability point of view, delivering environmental benefits with limited research focussing on economic benefits from sustaining competitive advantage. However, as argued earlier most of the findings are either conceptual or limited when it comes to general application. Hence, the fourth theme of the product/service system design has emerged - the necessity to develop a generic approach for designing a product/service system and to understand the various methods, tools and techniques available to support it (such as an amended version of QFD). It is essential to explore the organisational capabilities required and their associated resources when designing the servitised offering. In today's economic environment, many businesses (customers) are concentrating on their core competencies and outsourcing the less important activities and this is one of the rationalisations for servitisation from a supplier perspective. The organisation that provides servitised offerings to its customers could, in turn, outsource some of the elements of these offerings to its own suppliers. This leads to the fifth theme of supply network. It is necessary to explore how an organisation can renew its relationship with its suppliers in their journey towards servitisation, and the literature on this aspect is scarce. Previous research supports this need for the construction of relationships to enhance loyalty among consumers and strengthen alliances among parties involved in the business (Aurich et al., 2010). The research agenda that emerges is to understand how organisations should vertically integrate with suppliers and to what extent this proves beneficial.

Exploring the organisational architecture is the sixth theme. As reported in the previous section, two lines of enquiry were identified by Baines et al. (2009), namely structural and infrastructural changes. In line with their study, further research is needed to explore, validate and generalise the findings. One of the key elements within this architecture that need further exploration is knowledge management and the key challenge is to explore ways of capturing and managing knowledge throughout the journey of to servitised offerings.

It has been suggested that performance measurement should transform business strategy and service design to deliver value-in-use (Ostrom et al., 2010). However today, the majority of customer-facing measures, such as on-time delivery, flexibility, responsiveness, accuracy of documentation and even customer satisfaction, tend to focus on value-in-exchange rather than value-in-use-through-life (Bititci et al., 2012). This leads to the seventh theme of performance measurement, which emphasises the identification of metrics to measure value-in-use-throughlife. It would also be interesting to explore whether it is beneficial for the organisation to measure or involve customers in the evaluation of value-in-use-through-life.

The eighth theme is the cultural transition from product to service oriented thinking. It is not sufficient for service engineers to demonstrate technical skills such as repairing and fixing equipment they also need to demonstrate people skills such as the ability to communicate and train the user when appropriate. Although a few researchers (Reinartz and Ulaga, 2008; Spring 
and Araujo, 2009; Ng et al., 2011) have, to some extent, explored this issue, further research needs to be done to explore the required people skills in the servitisation journey. It will be essential for the organisations to find the appropriate behaviours and the ways of developing and transforming them. It is also useful to explore different kinds of management styles that are suitable in this journey.

The holistic framework presented above represents an agenda for research and exploration in practice. . Research, particularly action research, could play an important part in this. From an analysis of the extant literature, it is clear that the servitisation research agenda has been focussed predominantly on complex engineering service systems covering maintenance, repair and overhaul (MRO) services in support of the core product. However, the dearth of knowledge and evidence in this research field has excluded organisations operating in non-engineering sectors from adopting servitisation. Addressing the eight challenges identified above will have a direct impact on businesses and their willingness to adopt servitisation in order to retain and increase competitive advantage. Practitioners will be better equipped with the necessary knowledge to support decision-making in their transition to servitisation. As we have pointed out in this paper, servitisation on one hand has the potential to generate higher revenues and customer satisfaction. On the other hand, it has huge potential for contributing to the sustainability agenda, thus bringing synergistic impact on environment and society.

\subsection{Management Implications}

Manufacturing organisations are transitioning towards servitisation for a variety of reason: economic, strategic and environmental (Neely, 2012). These include competitive pressures from low-cost rivals emerging in developing counties, coupled with constraints on demand in developed countries caused by an over-saturated product base in many sectors. There is a need to increase product differentiation in such sectors, and a desire to retain customers by lockingout competitors (Neely, 2012). Thus servitisation and the concomitant opportunities, through value co-creation, to lock-in customers and build barriers to entry by rivals, is very close to the notion of how organisations create and sustain competitive advantage through the cospecialisation of complementary assets to create value in new and innovative ways (Milgrom and Roberts,1990; Teece, 1986).

There are two overriding strategic issues that need to be addressed by business organisations seeking to develop servitisation that utilise the co-creation of value to lock-in customers for the whole life of a value proposition. The first issue concerns the building and coordination of integrated services with their product to serve extremely narrow market segments (of perhaps just one customer). It is a challenge exacerbated by the fact that for servitisation to succeed in its mission, the process of value co-creation must be managed not only by the end-customer and product-service provider jointly, but also across multiple dyads throughout a value chain configured to facilitate servitisation. Success depends on the willingness of both downstream value co-creation partners (customers) and upstream value co-creation partners (suppliers of goods and services) to be locked into servitisation for the duration of the value proposition lifecycle. This requires customers, product-service providers and other value co-creation partners to embrace a cultural change in the way that a co-specialised value chain is managed, how asset development and ownership is perceived, and the way rewards and risks are 
distributed. The second issue is the need to manage context variety within the business organisation. In other words, the challenge of equipping organisations with the capability to create and manage multiple or flexible servitisation for narrow market segments with significantly differing value requirements and operational contexts. This may conceivably involve transitioning the organisation from a traditional focus on product-based business units (concerned with the management of product lifecycles) to one of servitisation portfolio stewardship concerned with the evolution of value co-creation positions.

The eight challenges framework discussed in this paper poses a series of questions about which practitioners would be advised to consider before embarking on their journey toward servitisation. The framework may potentially be developed into an audit or assessment tool to check organisation's maturity in dealing with these strategic issues.

\subsection{Conclusion}

In conclusion, it is not the authors' intention in this paper to criticise the extant literature on servitisation, but the comments serve more to remind the reader of the complex nature of the task ahead of us as researchers. It is, therefore, imperative to pull the various research streams together in a holistic approach with wider participation from industry, i.e. engineering and nonengineering sectors. Furthermore, the frame of reference needs to be widened to focus on the value perceptions and operational interactions throughout servitisation, and lengthened to capture the dynamics of the system across sectors and multiple time periods - longitudinal studies have much to offer here. The themes themselves suggest operational implications for the practice of management in terms of the configuration, management and measurement of organisations. If the academic research community is to develop a more complete picture and understanding of servitisation it needs to move from a disciplinary (silo-based) focus to a more holistic mind set incorporating layers of complementary research outputs. The limitation of this research is that we have clustered our analysis into eight research challenges. Though this is our core contribution, there is a possibility that some richness of previous work is lost. This is based on our interpretation of our analysis of previous research and remains to be tested across wider audience. Hence, the classification and the holistic framework should be carefully interpreted in the contextual needs of organisations in which it is applied. Our analysis provides a robust framework for future multi- and inter-disciplinary research which in itself, would test the themes in practice leading to application in the practice of management as well as the validation of the conceptual framework.

\section{References}

Allan, G. (2003). A critique of using grounded theory as a research method. Electronic Journal of Business Research Methods, 2(1), 1-10. http://www.ejbrm.com/vol2/v2-i1/issue1-art1$\underline{\text { allan.pdf }}$

An, Y., Lee, S. and Park, Y. (2008). Development of an integrated product-service roadmap with QFD. International Journal of Service Industry Management, 19(5), 621-638.

Anderson, E.W. (2006). Invited Commentary: Linking Service and Finance. Marketing Science, 25(6), 587-589. 
Anderson, J.C. and Narus, J.A. (1995). Capturing the value of supplementary services. Harvard Business Review, 73(1), 75-83.

Aurich, J.C., Fuchs, C. and Wagenknecht, C. (2006). Life cycle oriented design of technical product-service systems. Journal of Cleaner Production, 14(17), 1480-94.

Aurich, J.C., Wolf, N., Siener, M. and Schweitzer, E. (2010). Configuration of product-service systems. Journal of Manufacturing Technology Management, (20)5, 591-605.

Baines, T., Lightfoot, H. and Smart, P. (2011). Servitization within manufacturing: Exploring the provision of advanced services and their impact on vertical integration. Journal of Manufacturing Technology Management, 22(7), 947-954.

Baines, T.S., Lightfoot, H., Peppard, J., Johnson, M., Tiwari, A., Shehab, E. and Swink, M. (2009). Towards an operations strategy for product-centric servitization. International Journal of Operations and Production Management, 29(5), 494-519.

Baines, T., Lightfoot, H., Smart, P. and Fletcher, S. (2013). Servitization of manufacture: Exploring the deployment and skills of people critical to the delivery of advanced services. Journal of Manufacturing Technology Management, 24(4), 637-646.

Baines, T. and Lightfoot, H. W. (2014). "Servitisation of the manufacturing firm: Exploring the operations practices and technologies that deliver advanced services." International Journal of Operations and Production Management 34(1): 2-35

Bakos, Y. and Brynjolfsson, E. (1999). Bundling information goods: pricing, profits and efficiency. Management Science, 45(12), 1613-30.

Barnett, N. J., Parry, G., Saad, M., Newnes, L. B. and Goh, Y. M. (2013). Servitization: Is a paradigm Shift in the Business Model and Service Enterprise Required? Strategic Change, $22,145-156$.

Barquet, A. P. B., Oliveira, M. G. de, Amigo, C. R., Cunha, V. P., and Rozenfeld, H. (2013). Employing the business model concept to support the adoption of product-service systems (PSS). Industrial Marketing Management, 42(5), 693-704.

Bastl, M., Johnson, M., Lightfoot, H. and Evans, S. (2012), Buyer-supplier relationships in a servitized environment: An examination with Cannon and Perreault's Framework. International Journal of Operations and Production Management, 32(6), 650-675.

Benedettini, O. and Neely, A. (2012). Factors Influencing Service Complexity: The Perspectives of Servitized Manufacture. EurOMA Conference Proceedings, 1-5 July, Amsterdam, Netherlands.

Beuren, F. H., Ferreira, M. G. G. and Miguel, P. A. C. (2013). Product-service systems: a literature review on integrated products and services. Journal of Cleaner Production, 47, 222-231.

Bititci U. S., Garengo P., Dorfler V. and Nudurupati S. S. (2012). Performance Measurement: Challenges for Tomorrow. International Journal of Management Reviews, 14, 305-327.

Brady, A., Davies, A. and Gann, D.M. (2005). Creating value by delivering integrated solutions. International Journal of Project Management, 23(5), 360-365. 
Brezet, J.C., Bijma, A. S., Ehrenfeld, J. and Silvester, S. (2001). The Design of Eco-Efficient Services; Method, Tools and Review of the Case Study Based 'Designing Eco-Efficient Services. Delft: Dutch Ministries of Environment (VROM) and Delft University of Technology.

Bullinger, H., Fähnrich, K. and Meiren, T. (2003). Service engineering--methodical development of new service products. International Journal of Production Economics, $85(3), 275-87$.

Cook, M. B., Bhamra, T. A. and Lemon, M. (2006). The transfer and application of Product Service Systems: from academia to UK manufacturing firms. Journal of Cleaner Production, 14 (17), 1455-65.

Cranfield, D. J. and Taylor, J. (2008). Knowledge management and higher education: a UK Case Study" The Electronic Journal of Knowledge Management 6 (2) 85 - 100, available online at www.ejkm.com

Denyer, D. and Tranfield, D. (2008). Producing a systematic review. In Buchanan, D. (Ed.), The Sage Handbook of Organizational Research Methods (pp. 671-689). London: Sage.

Edvardsson, B., Gustafsson, A., Johnson, M.D. and Sanden, B. (2000). New Service Development and Innovation in the New Economy. Studentlitteratur, Lund.

Fang, E., Palmatier, R. and Steenkamp, J. (2008). Effect of Service Transition Strategies on Firm Value. Journal of Marketing, 72(9), 1-14.

Geng, X., Chu, X., Xue, D., Zhang, Z., (2010). An integrated approach for rating engineering characteristic's final importance in product-service system development. Journal Computers and Industrial Engineering, 59(4), 585-594.

Glaser, B, and Strauss, A. (1967)."The discovery of grounded theory." London: Weidenfeld and Nicholson.

Goedkoop, M. J., Van Halen, C. J. G., Riele, H.R.M. and Rommens P.J.M. (1999). Product Service Systems, Ecological and Economic Basics. The Hague: Dutch Ministries of Environment (VROM) and Economic Affairs (EZ).

Gronroos, C. (2000). Service Management and Marketing. Wiley, Chichester.

Gummesson E. and Polese F. (2009). B2B is not an island! Journal of Business and Industrial Marketing, 24(5/6), 337-350.

Heineke, J. and Davis, M. (2007). The emergence of service operations management as an academic discipline. Journal of Operations Management, (25)2, 364-74.

Johansson, C., Hicks B, Larsson A. and Bertoni M. (2011). Knowledge maturity as a means to support decision making during product service systems development projects in the aerospace sector. Project Management Journal, 42(2), 32-50.

Johnstone, S., Dainty, A. and Wilkinson, A. (2009). Integrating products and services through life: an aerospace experience. International Journal of Operations and Production Management, 29(5), 520-538.

Lamvik, T. (2001). Improving environmental performance of industrial products through product service systems. Norwegian University of Science and Technology. 
Lovelock, C. H. and Gummesson, E. (2004). Whither Services Marketing? In Search of a New Paradigm and Fresh Perspectives. Journal of Service Research, 7(1), 20.

Manzini, E. and C. Vezzoli (2003). A strategic design approach to develop sustainable product service systems: examples taken from the environmentally friendly innovation' Italian prize. Journal of Cleaner Production, 11(8), 851-57.

Martinez, V., Bastl, M., Kingston, J. and Evans, S. (2010). Challenges in transforming manufacturing organisations into product-service providers. Journal of Manufacturing Technology Management, 21(4), 449-469.

Mathe, H. and Shapiro, R. (1993). Integrating service strategy in the manufacturing firm. Chapman and Hall, London.

McAloone, T. C. and Andreasen, M. M. (2004). Design for utility, sustainability and societal virtues: Developing Product Service Systems, International Design Conference Proceedings. Dubrovnik.

Meier, H., Roy, R., Seliger, G., (2010). Integrated Product-Service Systems - IPS2. CIRP Annals - Manufacturing Technology.

Milgrom P. and Roberts J. (1990). The economics of modern manufacturing: technology, strategy and organisation, American Economic Review, 80(3), 511-528.

Miller, D., Hope, Q., Eisengstat, R., Foote, N. and Galbraith, J. (2002). The problem of solutions: balancing clients and capabilities. Business Horizons, 45(2), 3-12.

Mittal, V., Kumar, P., and Tsiros, M. (1999). Attribute-Level Performance, Satisfaction, and Behavioral Intentions over Time: A Consumption-System Approach. Journal of Marketing, 63(2), 88-101.

Mont, O. (2003). Product service systems and sustainable consumption. Journal of Cleaner Production, 11(8), 815-933.

Mont, O. K. (2002). Clarifying the concept of product-service system. Journal of Cleaner Production, 10(3), 237-245.

Morelli N. (2009). Service as value co-production: reframing the service design process. Journal of Manufacturing Technology Management, 20(5), 568-590.

Morelli, N. (2002). Designing Product/Service Systems: A Methodological Exploration. Design Issues, 18(3), 3-17.

Neely, A. (2007). The servitisation of manufacturing: an analysis of global trends. European Operations Management Conference Proceedings, Ankara.

Neely, A. (2012). Society's Grand Challenges: What Role for Services?, Working Paper, Cambridge Service Alliance, University of Cambridge.

Neu, W.A. and Brown, S.W. (2008). Manufacturers forming successful complex business services: designing an organization to fit the market. International Journal of Service Industry Management, 19(2), 232-51.

$\mathrm{Ng}$ I. and Nudurupati S. S. (2010). Outcome-Based Service Contracts In the Defence Industry Mitigating the Challenges. Journal of Service Management, 21(5), 656-674. 
Ng I., Nudurupati S. S. and Williams J. (2011). Redefining Organizational Capability for Value Co-creation in Complex Engineering Service Systems by Ng, I.C.L., Wild, P., Parry, G., MacFarlane, D. and Tasker, P. (Eds.) in Complex Engineering Service Systems: Concepts and Research, by Springer Publishers.

Oliva, R. and Kallenberg, R. (2003). Managing the transition from products to services. International Journal of Service Industry Management, 14(2), 160-72.

Ostrom, A., Bitner, M., Brown, S., Burkhard, K., Goul, M., Smith-Daniels, V., Demirkan, H. and Rabinovich, E. (2010). Moving Forward and Making a Difference: Research Priorities for the Science of Service. Journal of Service Research, 13(1), 4-36.

Prahalad, C. K. and Ramaswamy, V. (2004). The Future of Competition Co-Creating Unique Value with Customers. Harvard University Press, Cambridge, MA.

Quinn, J.B., Doorley, T.L. and Paquette, P.C. (1990). Beyond products: service-based strategies. Harvard Business Review, 68(2), 58-67.

Raddats C. and Easingwood C. (2010). Services growth options for B2B product-centric businesses. Industrial Marketing Management, 39, 1334-1345.

Reinartz, W. and Ulaga, W. (2008). How to sell service more profitably. Harvard Business Review, 86(5), 90-96.

Rousseau, D., Manning, J. and Denyer, D. (2008). Evidence in management and organizational science: assembling the field's full weight of scientific knowledge through syntheses. Academy of Management Annals, 2, 475-515.

Sakao T., Sandstrom, G. and Matzen, D. (2009). Framing research for service orientation of manufacturers through PSS approaches. Journal of Manufacturing Technology Management, 20(5), 754-778

Schmenner, R.W. (2009). Manufacturing, service, and their integration: some history and theory. International Journal of Operations and Production Management, 29(5), 431-443.

Smith, L., Maull, R. and Ng, I. C. L. (2014). Servitization and operations management: a service dominant-logic approach, International Journal of Operations and Production Management, 34(2), 242-269.

Spohrer, J. and Maglio, P. P. (2008). Toward Systematic Service Innovations to Accelerate CoCreation of Value. Production and Operations Management,17(3), 238-246.

Spring, M. and Araujo, L. (2009). Service, services and products: rethinking operations strategy. International Journal of Operations and Production Management, 29(5), 444-467.

Teece, D. J. (1986). Profiting from technological innovation: implications for integration, collaboration, licensing and public policy. Research Policy, 15, 285-305.

Tukker, A. and Tischner, U. (2006). Product-services as a research field: past, present and future. Reflections from a decade of research. Journal of Cleaner Production, 14(17), 155256.

Tukker, Arnold (2004). Eight types of product-service system: eight ways to sustainability? Experiences from SusProNet. Business Strategy and the Environment, 13(4), 246-260. 
Ulaga, W. and Reinartz, W. (2011). Hybrid Offerings: How Manufacturing Firms Combine Goods and Services Successfully. Journal of Marketing, 75(11), 5-23.

Vandermerwe, S. and Rada, J. (1988). Servitisation Of Business: Adding Value By Adding Services. European Management Journal, 6(4), 314-324.

Vargo, S. L. and Lusch, R. F. (2004). Evolving to a New Dominant Logic for Marketing. Journal of Marketing, 68(1), 1-17.

Vargo, S. L. and Lusch, R. F. (2008). Service-dominant Logic: Continuing the Evolution. Journal of the Academy of Marketing Science, 36(1), 1-10.

White, A., Stoughton, M. and Feng, L. (1999). Servicizing: the quiet transition to extended producer responsibility. Boston: Tellus Institute.

Windahl, C., Andersson, P., Berggren, C. and Nehler, C. (2004). Manufacturing firms and integrated solutions: characteristics and implications. European Journal of Innovation Management, 7(3), 218-228.

Wise, R. and Baumgartner, P. (1999). Go Downstream: The New Profit Imperative in Manufacturing. Harvard Business Review, 77(5), 133-141.

Yang, X., Moore, P., Pu, J.S., Wong, C.B., (2009). A practical methodology for realizing product service systems for consumer products. Computers and Industrial Engineering, 56(1), 224-235.

Zaring, O (2001). Creating Eco-Efficient Producer Services: Report of an EU project. Gothenburg: Gothenburg Research Institute.

Zeithaml, V. A., Bitner, M. J. and Gremler, D. D. (2006). Services Marketing. Singapore: McGraw Hill: International Edition. 